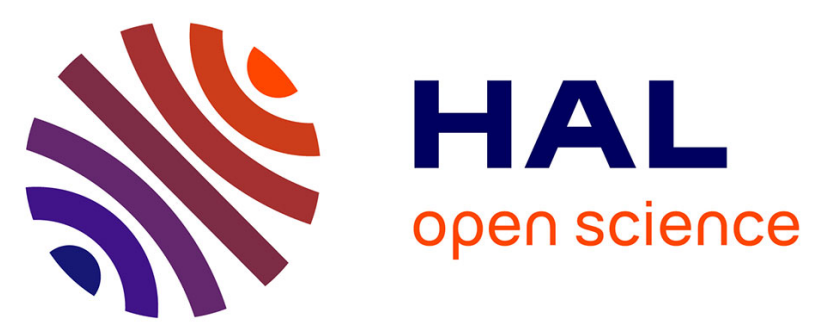

\title{
Effects of neurotransmitters, gut hormones, and inflammatory mediators on mucus discharge in rat colon
}

Pascale Plaisancié, Aline Barcelo, Frederique Moro, Jean Claustre, Jean-Alain Chayvialle, Jean-Claude Cuber

\section{- To cite this version:}

Pascale Plaisancié, Aline Barcelo, Frederique Moro, Jean Claustre, Jean-Alain Chayvialle, et al.. Effects of neurotransmitters, gut hormones, and inflammatory mediators on mucus discharge in rat colon. AJP - Gastrointestinal and Liver Physiology, 1998, 275 (5), pp.G1073-G1084. hal-02698136

\section{HAL Id: hal-02698136 \\ https://hal.inrae.fr/hal-02698136}

Submitted on 1 Jun 2020

HAL is a multi-disciplinary open access archive for the deposit and dissemination of scientific research documents, whether they are published or not. The documents may come from teaching and research institutions in France or abroad, or from public or private research centers.
L'archive ouverte pluridisciplinaire HAL, est destinée au dépôt et à la diffusion de documents scientifiques de niveau recherche, publiés ou non, émanant des établissements d'enseignement et de recherche français ou étrangers, des laboratoires publics ou privés. 
Pascale Plaisancié, Aline Barcelo, Frederic Moro, Jean Claustre, Jean-Alain

Chayvialle and Jean-Claude Cuber

Am J Physiol Gastrointest Liver Physiol 275:1073-1084, 1998.

You might find this additional information useful...

This article cites 29 articles, 13 of which you can access free at:

http://ajpgi.physiology.org/cgi/content/full/275/5/G1073\#BIBL

This article has been cited by 9 other HighWire hosted articles, the first 5 are:

Dimethylthiourea pretreatment inhibits endotoxin-induced compound exocytosis in goblet cells and plasma leakage of rat small intestine

S. P. Liu, C. Y. Chang, W. H. Huang, Y. S. Fu, D. Chao and H. T. Huang

J. Electron Microsc. (Tokyo), April 1, 2010; 59 (2): 127-139.

[Abstract] [Full Text] [PDF]

Luminal leptin activates mucin-secreting goblet cells in the large bowel

P. Plaisancie, R. Ducroc, M. E. Homsi, A. Tsocas, S. Guilmeau, S. Zoghbi, O. Thibaudeau and A.

Bado

Am J Physiol Gastrointest Liver Physiol, April 1, 2006; 290 (4): G805-G812.

[Abstract] [Full Text] [PDF]

Vasoactive intestinal peptide upregulates MUC2 intestinal mucin via CREB/ATF1

R. Hokari, H. Lee, S. C. Crawley, S. C. Yang, J. R. Gum Jr, S. Miura and Y. S. Kim Am J Physiol Gastrointest Liver Physiol, November 1, 2005; 289 (5): G949-G959.

[Abstract] [Full Text] [PDF]

Effects of peptides derived from dietary proteins on mucus secretion in rat jejunum

J. Claustre, F. Toumi, A. Trompette, G. Jourdan, H. Guignard, J. A. Chayvialle and P. Plaisancie Am J Physiol Gastrointest Liver Physiol, September 1, 2002; 283 (3): G521-G528.

[Abstract] [Full Text] [PDF]

Dietary Fish Oil Increases Acetylcholine- and Eicosanoid-Induced Contractility of Isolated Rat Ileum

G. S. Patten, M. Y. Abeywardena, E. J. McMurchie and A. Jahangiri

J. Nutr., September 1, 2002; 132 (9): 2506-2513.

[Abstract] [Full Text] [PDF]

Medline items on this article's topics can be found at http://highwire.stanford.edu/lists/artbytopic.dtl on the following topics:

Biochemistry .. Mucus Glycoproteins

Endocrinology .. Bombesin

Biophysics .. Calcitonin Gene-Related Peptide

Physiology .. Large Intestine

Physiology .. Colon

Physiology .. Rats

Updated information and services including high-resolution figures, can be found at:

http://ajpgi.physiology.org/cgi/content/full/275/5/G1073

Additional material and information about AJP - Gastrointestinal and Liver Physiology can be found at: http://www.the-aps.org/publications/ajpgi

This information is current as of September 6, 2010 .

AJP - Gastrointestinal and Liver Physiology publishes original articles pertaining to all aspects of research involving normal or abnormal function of the gastrointestinal tract, hepatobiliary system, and pancreas. It is published 12 times a year (monthly) by the American Physiological Society, 9650 Rockville Pike, Bethesda MD 20814-3991. Copyright @ 1998 by the American Physiological Society. ISSN: 0193-1857, ESSN: 1522-1547. Visit our website at http://www.the-aps.org/. 


\title{
Effects of neurotransmitters, gut hormones, and inflammatory mediators on mucus discharge in rat colon
}

\author{
PASCALE PLAISANCIE, 1,2 ALINE BARCELO, ${ }^{1}$ FREDERIC MORO, ${ }^{1} \mathrm{~J}$ EAN CLAUSTRE, ${ }^{1}$ \\ JEAN-ALAIN CHAYVIALLE, ${ }^{1}$ AND JEAN-CLAUDE CUBER ${ }^{1,2}$ \\ IInstitut National de la Santé et de la Recherche Médicale U-45, Hôpital Edouard Herriot, 69347 \\ Lyon Cedex 03; and 'Laboratoire d'E cologie et de Physiol ogie du Système Digestif, Institut National \\ de la Recherche Agronomique, Centre de Recherche de J ouy-en-J osas, 78352 J ouy-en-J osas, France
}

\begin{abstract}
Plaisancié, Pascale, Aline Barcelo, Frederic Moro, J ean Claustre, J ean-Alain Chayvialle, and J ean-Claude Cuber. Effects of neurotransmitters, gut hormones, and inflammatory mediators on mucus discharge in rat colon. Am. J. Physiol. 275 (Gastrointest. Liver Physiol. 38): G1073G1084, 1998.-The effect of potential mediators of mucus secretion was investigated in the isolated vascularly perfused rat col on by using a sandwich enzyme-linked immunosorbent assay for rat colonic mucin and by histochemical analysis. Bethanechol (100-200 $\mu \mathrm{M})$, bombesin (100 nM), and vasoactive intestinal peptide (VIP, $100 \mathrm{nM})$ provoked a dramatic mucin discharge (maximal response at 900,900 , and $600 \%$ of control loops, respectively). VIP-stimulated mucin secretion was abol ished by tetrodotoxin, whereas atropine was without effect. In contrast, both tetrodotoxin and atropine significantly decreased mucin release induced by bombesin. I soproterenol or calcitonin gene-related peptide was without effect. Serotonin (1-5 $\mu \mathrm{M})$ and peptide $Y Y(10 \mathrm{nM})$ evoked mucin discharge, whereas glucagon-like peptide-1 did not release mucin. Finally, bromolasalocid $(20 \mu \mathrm{M})$, interleukin-1 $\beta(0.25$ $\mathrm{nM})$, sodium nitroprusside (1 mM), and dimethyl-PGE 2 (2.5 $\mu \mathrm{M})$ induced mucus discharge. The results demonstrated a good correlation between the immunological method and histological analysis. In conclusion, these findings suggest a role for the enteric nervous system, the enteroendocrine cells, and resident immune cells in mediation of colonic mucus release.
\end{abstract}

colonic mucin release; enzyme-linked immunosorbent assay; cavitation; isolated colon

THE INTESTINAL MUCOSA is covered by a mucus gel layer that plays important physiological roles including lubrication, protection against colonization by pathogenic bacteria and their toxins, protection against luminal proteases arising from bacterial and mucosal cells, and constitution of a diffusion barrier for small molecules (11). In the large bowel, mucus also represents a nutrient for the strict anaerobic bacteria. The major structural components in mucus are mucins, which are high molecular-weight glycoproteins produced by goblet cells of the surface epithelium (11). These cells store mucin in apically located granules that are secreted at a slow baseline rate to maintain the mucus coat over the epithelium. In response to stimulation, intestinal goblet cells may dramatically accelerate their discharge of mucins by way of two processes $(10,32)$. In many mucus cells, a phenomenon of compound exocytosis is induced, resulting in deep apical membrane cavitation that is visible under the microscope. Some intestinal mucus cells can also respond to stimulation by another process, presumably by accelerating single- granule exocytosis. Although mucus plays a central role in mucosal protection, factors that govern this discharge of mucus are not fully defined, particularly in the colon.

Colonic mucus cells are located in the vicinity of enteric nerves, enteroendocrine cells, and resident immune cells, which suggests a potential role of neurotransmitters, hormonal peptides of thelarge bowel, and inflammatory mediators. This hypothesis is supported by the observation that cholinergic agents stimulate colonic mucus discharge both in vivo (31) and in mucosal explants (24). Experiments performed with several colonic mucus-secreting cell lines also showed that carbachol $(19,21)$, vasoactive intestinal peptide (VIP) (21), nitric oxide (NO) (3), interleukin (IL)-1 (18), and $\mathrm{PGE}_{2}$ (26) stimulate colonic mucin discharge. However, the colonic wall contains many other candidates to influence mucus secretion.

The present study was then undertaken to investigate in detail the influence of various neurotransmitters, hormonal peptides, and inflammatory mediators on colonic mucin secretion. For this purpose, we used the preparation of isolated vascularly perfused rat colon, a new model to study mucin secretion. In this preparation, mucus cells keep their physiological orientation and environment and are submitted to welldefined luminal, neural, and blood-borne stimuli in a manner that eliminates influences potentially encountered in vivo. A sandwich ELISA was developed to measure accuratel y mucin rel eased from isolated vascularly perfused rat colon. Discharge of mucus granule was also evaluated by histological analysis. These experiments indicate that colonic mucus cells can respond to different classes of mediators produced by nerves, enter oendocrine cells, and the immune system.

\section{MATERIALS AND METHODS}

Materials

The following reagents were purchased from Sigma (Saint Quentin-Fallavier, France): guanidinium hydrochloride, phenylmethylsulfonyl fluoride (PMSF), dithiothreitol (DTT), Tris, orcinol, bovine thyroglobulin, gum arabic, proteinase K, biotin disulfide $\mathrm{N}$-hydroxysuccinimide ester, polyoxyethylenesorbitan (Tween 20), o-phenylenediamine dihydrochloride tablets (OPD), bovine albumin (BA, lyophilized powder), avidin-peroxydase conjugate, bethanechol, isoproterenol, calcitonin gene-related peptide (CGRP) (rat CGRP-I), peptide YY (PYY), glucagon-like peptide-1-(7-36) amide, serotonin, VIP, bombesin (BBS), sodium nitroprusside (SNP), IL-1 $\beta$, 16,16-dimethyl-PGE $2\left(\mathrm{dmPGE}_{2}\right)$, TTX, and atropine. EDTA was supplied by Merck (Nogent-sur-Marne, F rance). Bromola- 
salocid was kindly provided by Roche Discovery Welwyn (Welwyn Garden City, England). Electrophoresis products were purchased from Bio-Rad (I vry sur Seine, France). Cesium chloride $(\mathrm{CsCl})$ and DIG Glycan detection kit were supplied by Boehringer Mannheim (Meylan, France). BSA (30\% solution) was purchased from Biovalori (Cassens, France). Hyperamine 25, a mixture of amino acids, was obtained from Braun medical (Boulogne, France).

\section{Methods}

ELISA for rat colonic mucin. PURIFICATION OF RAT COLONIC MUCIN. Male Wistar rats (Centre d'Elevage Dépré, Saint Doulchard, France) were killed by a lethal dose of pentobarbital sodium. Colonic mucins were then isolated from mucosal scrapings, essentially as previously described by Tytgat et al. $(33,34)$. Briefly, scrapings were homogenized in the dark for $24 \mathrm{~h}$ at $4^{\circ} \mathrm{C}$ in homogenization buffer, $\mathrm{pH} 7.5$ (6 M guanidinium hydrochloride, $50 \mathrm{mM}$ Tris, $1 \mathrm{mM}$ PMSF, $5 \mathrm{mM}$ EDTA, 100 mM DTT). Sulfhydride groups were carboxymethylated by adding $250 \mathrm{mM}$ iodoacetamide in the dark for another $24 \mathrm{~h}$. Mucins were then purified by equilibrium centrifugation on three consecutive $\mathrm{CsCl}$ density gradients (Centrikon T-2055 ultracentrifuge, TFT 50.38 rotor, $100,000 \mathrm{~g}, 70 \mathrm{~h}$ at $12^{\circ} \mathrm{C}$ ). The resulting gradients were fractionated into 12 equal fractions. For analysis, the fractions were dialyzed extensively against distilled water $\left(4^{\circ} \mathrm{C}, 24 \mathrm{~h}\right)$ and then assayed for hexoses using an orcinol assay at $540 \mathrm{~nm}$ (12). Protein content was measured by the method of Bradford (Bio-Rad), and nucleic acid detection was performed by absorbance at $260 \mathrm{~nm}$. The high molecular-weight nature of purified mucin was verified by SDS-PAGE and Western blot using an immunological detection system for glycoproteins (DIG Glycan detection kit) (14).

PREPARATION OF POLYCLONAL ANTISERUM AGAINST RAT COLONIC MUCIN. Antisera against rat colonic mucin (RCM), obtained in rabbits after repeated injections of the purified mucin $(250 \mu \mathrm{g})$, were tested for the presence of anti-rat colonic mucin antibody (anti-RCM) by performing dot-blot immunoassay. Briefly, serial dilutions (from 200 to 6.25 $\mu \mathrm{g} / \mathrm{ml}$ ) of purified mucin, BA, bovine thyroglobulin, or gum arabic were blotted on nitrocellulose. Blots were incubated with anti-RCM $(1: 1,000$ or 1:5,000). This was followed by incubation with goat anti-rabbit IgG conjugated to horseradish peroxydase $(1: 1,000)$. Blots were then devel oped using the electrochemiluminescence method (Pierce, Rockford, IL).

The polyclonal antiserum was then studied for epitope specificity. F or this purpose, purified mucin was digested with $0.1 \mathrm{mg} / \mathrm{ml}$ proteinase $\mathrm{K}$ in $50 \mathrm{mM}$ Tris, $\mathrm{pH} 7.4\left(1 \mathrm{~h}, 37^{\circ} \mathrm{C}\right)$, to test the reactivity toward protease-sensitive epitopes. The digested mucin was blotted on nitrocellulose and processed as described previously.

Determination of specific antibody titer in polyclonal antiserum was performed by dot blot with purified mucin. The highest titer was identified by the intensity of the signal. With the use of the serum with the highest antibody titer (45C), an immunoglobulin-rich fraction was prepared using DEAE-Sephadex A50 (pH 7.2). This was used to coat ELISA plates (as described in ELISA PROCEDURE) and was referred to as coating antibody $45 \mathrm{C}$ (c-45C). A part of theimmunoglobulinrich fraction was also used to prepare enzyme-labeled antibody (biotinylated-45C) for the ELISA using a succinimide ester of biotin (13).

IMMUNOHISTOCHEMISTRY. Recognition of mucin by antiRCM was studied histologically. Sections $(5 \mu \mathrm{m})$ of paraffinembedded colonic tissue were incubated with diluted normal blocking serum and then with anti-RCM antiserum (1:1,000 dilution). After washing in PBS, sections were sequentially exposed to biotinylated goat anti-rabbit antibody, avidinbi otinylated peroxydase complex, and 3,3'-diaminobenzidine solution. All thereagents were purchased from Vector Laboratories, Burlingame, CA. The sections were then counterstained, cleared, and mounted.

ELISA PROCEDURE. Wells of a microtiter plate (NUNCImmuno Plate; Polylabo Paul block \& cie, Strasbourg, France) were coated with $100 \mu$ l of diluted c-45C $(10 \mu \mathrm{g} / \mathrm{ml}$ in $50 \mathrm{mM}$ phosphate buffer) and incubated $1 \mathrm{~h}$ at $37^{\circ} \mathrm{C}$ and then overnight at $4^{\circ} \mathrm{C}$. On the following day, the microtiter plate was washed three times with PBS containing 0.1\% Tween (PBS-Tween, $\mathrm{pH}$ 7.2). The remaining binding sites in the wells were blocked by addition of $250 \mu$ l of PBS-Tween-BA (0.1 g albumin in $100 \mathrm{ml}$ PBS-Tween) for $1 \mathrm{~h}$ at room temperature, and the plate was washed again. At this stage, $100 \mu \mathrm{l}$ of sample diluted in PBS-Tween-BA were added for $1 \mathrm{~h}$ at room temperature. Then, after three washes, the wells were incubated with $100 \mu$ lo the biotinylated-45C diluted in PBS-Tween-BA $(7.5 \mu \mathrm{g} / \mathrm{ml})$ for $1 \mathrm{~h}$ at room temperature. After the wells were washed again, $100 \mu$ of avidin-peroxidase conjugate were added and allowed to bind for $1 \mathrm{~h}$ at room temperature. The plate was washed five times. One hundred microliters of the OPD solution were then added to each well, and the col or was al lowed to devel op in the dark for 5-10 min. The reaction was stopped by adding $25 \mu \mathrm{l}$ of $3 \mathrm{M}$ sulfuric acid to each well. The absorbance was read at $492 \mathrm{~nm}$ on a micro-E LISA plate reader. Purified mucin ranging in concentration from 0 to $500 \mathrm{ng} / \mathrm{ml}$ was treated in the same way as the test samples to obtain a mucin standard curve. All assays were performed in duplicate.

PREPARATION OF TISSUES FOR CROSS-REACTIVITY STUDIES. Scrapings (stomach, intestine, colon) from rat, mouse, and guinea pig were treated for reduction and carboxymethylation, as described in PURIFICATION OF RAT COLONIC MUCIN. Other rat tissues (lung, kidney, pancreas, liver, spleen, muscle) were first homogenized for $1 \mathrm{~min}$ using a homogenizer (UItra-Turrax, J anke and Kundel) and then treated as mentioned above. After dialysis $\left(4^{\circ} \mathrm{C}, 24 \mathrm{~h}\right)$, homogenates of scrapings and tissues were analyzed for mucin by E LISA and for protein by Bradford assay. Tissue mucin content was expressed according to protein content.

Study of mucin secretion and measurement of mucin. SURGICAL PREPARATION. The operative procedure to prepare an isolated vascularly perfused rat colon was previously described (27). Briefly, male Wistar rats (250-350 g) were anesthetized with pentobarbital sodium ( $50 \mathrm{mg} / \mathrm{kg}$ ip). The proximal and transverse colons were freed from their visceral fixations. The ileocolic veins and arteries were tied. Both ends of the col onic loop ( $10 \mathrm{~cm}$ in length) were then equipped with Silastic tubing. A metal cannula and a Silastic one were then quickly inserted into the superior mesenteric artery and portal vein, respectively. The arterial perfusion started immediately at a rate of $2.5 \mathrm{ml} / \mathrm{min}$ with a Krebs-Henseleit buffer $\left(2 \mathrm{mM} \mathrm{CaCl}, 6 \mathrm{mM} \mathrm{KCl}, 3.18 \mathrm{mM} \mathrm{NaH}_{2} \mathrm{PO}_{4}, 104 \mathrm{mM} \mathrm{NaCl}\right.$, $1 \mathrm{mM} \mathrm{MgSO}_{4}, 41.6 \mathrm{mM} \mathrm{NaHCO}, \mathrm{pH} 7.4$ ) containing $25 \%$ washed bovine erythrocytes, 3\% BSA, $5 \mathrm{mM}$ glucose, and 1\% hyperamine 25 ( $\mathrm{vol} / \mathrm{vol})$. The pressure of perfusion, continuously recorded with a mercury manometer, ranged from 55 to $75 \mathrm{mmHg}$. The colonic lumen was flushed out with prewarmed isotonic saline and then with air, and both ends of the intestinal loop were ligated. The preparation was then removed and transferred to a bath containing isotonic saline at $37^{\circ} \mathrm{C}$.

EXPERIMENTAL PROTOCOL. The experiments consisted of a 10-min equilibration period, followed by a 30-min period of stimulation. Immediately following the equilibration period, the loops were filled by injection with $1.0 \mathrm{ml}$ of prewarmed 
saline $\left(37^{\circ} \mathrm{C}\right)$. All vascularly perfused drugs and peptides were dissolved in the Krebs-Henseleit buffer supplemented with 3\% BSA. They were then delivered at a rate of 0.25 $\mathrm{ml} / \mathrm{min}$ through a catheter close to the vascular inflow. The drug concentrations represented the final concentrations in the arterial inflow cannula. The control group underwent a 10-min equilibration period, followed by a 30-min period during which $\mathrm{K}$ rebs-Henseleit buffer supplemented with 3\% BSA was administered to the vascular inflow $(0.25 \mathrm{ml} / \mathrm{min})$. The data from the controls were obtained from a separate group of animals. In some experiments, $1 \mu \mathrm{M}$ TTX or $10 \mu \mathrm{M}$ atropine infusion was started at the equilibration period and then lasted over the 30-min perfusion of secretagogues. Such experiments had a total duration of $40 \mathrm{~min}$. Oxygen saturation, glucose consumption (a measure of metabolic activity), and rate of glucose conversion to lactate (an indicator of anaerobic metabolism) remained constant during the perfusion period (27).

At the end of the experimental period, loops were cut at both ends. Fluid content was carefully collected. To remove mucus adherent to the mucosal surface, loops were carefully emptied by manual massage, subsequently flushed with 15-20 ml air, and drained. Luminal content (fluid content + adherent mucus gel) was weighed, sonicated, and frozen at $-20^{\circ} \mathrm{C}$ for subsequent determination of mucinlike immunoreactivity and luminal DNA content. The adherent mucous gel was taken into account because it represents a substantial part of the secreted immunoreactive material. The empty colonic loops were weighed, measured (cm), homogenized for 1 min in PBS using a homogenizer, and then stored at $-20^{\circ} \mathrm{C}$. Tissue homogenates were then analyzed for DNA content.

SAMPLE ANALYSIS. Samples of Iuminal contents were incubated for $24 \mathrm{~h}$ with $100 \mathrm{mM}$ DTT for reduction and were then assayed for ELISA reactivity. All luminal assays were performed in three dilutions (1:4,000, 1:8,000, and 1:16,000). Colonic loop homogenates were thawed and briefly homogenized. Aliquots were sonicated for $20 \mathrm{~s}$ and then analyzed for DNA content using the fluorimetric method of Hinegardner (15). The amount of mucin secreted from each loop was expressed as micrograms of mucin per milligram of tissue DNA. Samples of luminal content were also analyzed for DNA content. This analysis served as an indirect measure of tissue viability, and loops were discarded when luminal DNA content represented more than $2 \%$ of the total DNA (tissue DNA plus luminal DNA). Total luminal content (fluid content + adherent mucus gel) recovered from the lumen was expressed as milligrams of luminal content per centimeter of colonic loop.

Histological anal ysis and goblet cell morphology. HISTOLOGICAL TECHNIQUE. To provide an estimate of depletion of mucus stores from goblet cells, the effect of several pharmacological agents was also monitored by histological analysis, as described previously (28). Briefly, pieces of colon $(2-2.5 \mathrm{~cm})$ taken at the end of the isolated colon experiment were fixed into Karnovsky's fixative, processed in Epon, sectioned at 2 $\mu \mathrm{m}$, stained with alcian blue (AB, $\mathrm{pH} 2.5)$ followed by the periodic acid-Schiff reaction (PAS), and then counterstained with hematoxylin. The AB/PAS method yielded blue color when mostly acidic mucins were present, purple when neutral mucins were also present, and magenta when mainly neutral mucins were present. The corresponding cells were called stained mucus cells.

QUANTITATIVE HISTOLOGY. An estimate of depletion of mucus stores from goblet cells may be provided microscopically (29, 32). In brief, intestinal goblet cells can respond to stimulation either by a process of compound exocytosis resulting in deep apical membrane cavitation or by another mechanism that decreases the intracellular mucus store but without apical cavitation $(10,32)$. When the latter mechanism leads to total depletion of mucus granules, goblet cells are no longer stained by AB/PAS and appear indistinguishable from other epithelial cells. Thus the extent of mucus secretion may be quantified both by assessing the number of mucus cells per crypt section and the percentage of cavitated mucus cells per preparation. For this purpose, 15-30 crypts per slide were analyzed, and 500-1,000 mucus cells were counted per sample of colon. A crypt was considered when it was cut along or nearly along the length of the crypt lumen (at least two-thirds of the length of the crypt). Progressing from the crypt base to crypt opening, all stained mucus cells belonging to the epithel ium were counted on both sides of the lumen. All mucus cells were evaluated for the presence of cavitation of their apical membrane. A mucus cell with clear apical indentation into the intracellular store of mucus granules was taken as showing signs of the cavitation that accompanies recent compound exocytotic activity. Four to seven rat colons were prepared for each set of experiments. All slides were analyzed by a single investigator who was blinded to the drug treatment.

Statistical analysis. Data are presented as mean values \pm SE . Data were compared using Student's t-test (comparison of 2 means) or an analysis of variance with a Bonferroni test (comparison of $>2$ means) where appropriate. $\mathrm{P}<0.05$ was considered significant.

\section{RESULTS}

\section{Devel opment of I mmunoassay for RCM}

RCM, used for raising antiserum in rabbits, was isolated from colonic mucosal scrapings by applying three successive $\mathrm{CsCl}$ density gradients (Fig. 1). After the third gradient, mucin-containing fractions were pooled and stored lyophilized at $-20^{\circ} \mathrm{C}$. By immunohistochemistry, the antiserum developed against purified RCM reacted specifically with colonic goblet cells as well as with the mucus blanket (Fig. 2). In a control experiment, purified antigen was preincubated for 30 min at $37{ }^{\circ} \mathrm{C}$ with the antiserum. Substituting antiserum for the antigen-antiserum preincubation mix showed no reaction toward colonic mucus cells. Similarly, substituting anti-RCM antiserum for PBS produced no reaction toward mucus cells. The antiserum was also tested for mucin specificity and epitope identification by immunodetection on dot blot. Our results showed that the antiserum reacted with the purified mucin. No reaction was observed with BA, bovine thyroglobulin, and gum arabic. SDS-PAGE of the purified mucins and Western blotting with our antibody revealed a single band corresponding to high molecularweight immunoreactive material (not shown). Finally, proteolytic digestion of the purified mucin with proteinase $K$ resulted in a very strong decrease in reactivity on dot bl ot (data not shown), thus indicating that proteasesensitive domains in mucins are crucial for binding to the antibodies.

A sandwich ELISA for RCM was then set up using the anti-RCM antiserum. A typical standard curve obtained by using increasing concentrations of purified mucin from 0 to $500 \mathrm{ng} / \mathrm{ml}$ is shown in Fig. 3A. Linearity was obtained between 8 and 500 ng mucin/ $\mathrm{ml}$. The mucin specificity of the antiserum was further 
examined by ELISA of scraping and tissue homoge nates. The extracts of rat colon gave the highest response. Rat stomach and small intestine reacted to a lesser extent (Fig. 3B). Homogenates of lung, kidney, pancreas, liver, spleen, muscle, and serum did not react in ELISA. No cross-reactivity was detected with mouse and guinea pig gastric, intestinal, or colonic scrapings. Serial dilutions of luminal samples taken from control preparation or from col onic loop after a 30-min stimulation period with bethanechol or $\mathrm{dmPGE}_{2}$ gaveresults in ELISA that could be superimposed on the mucin stan-
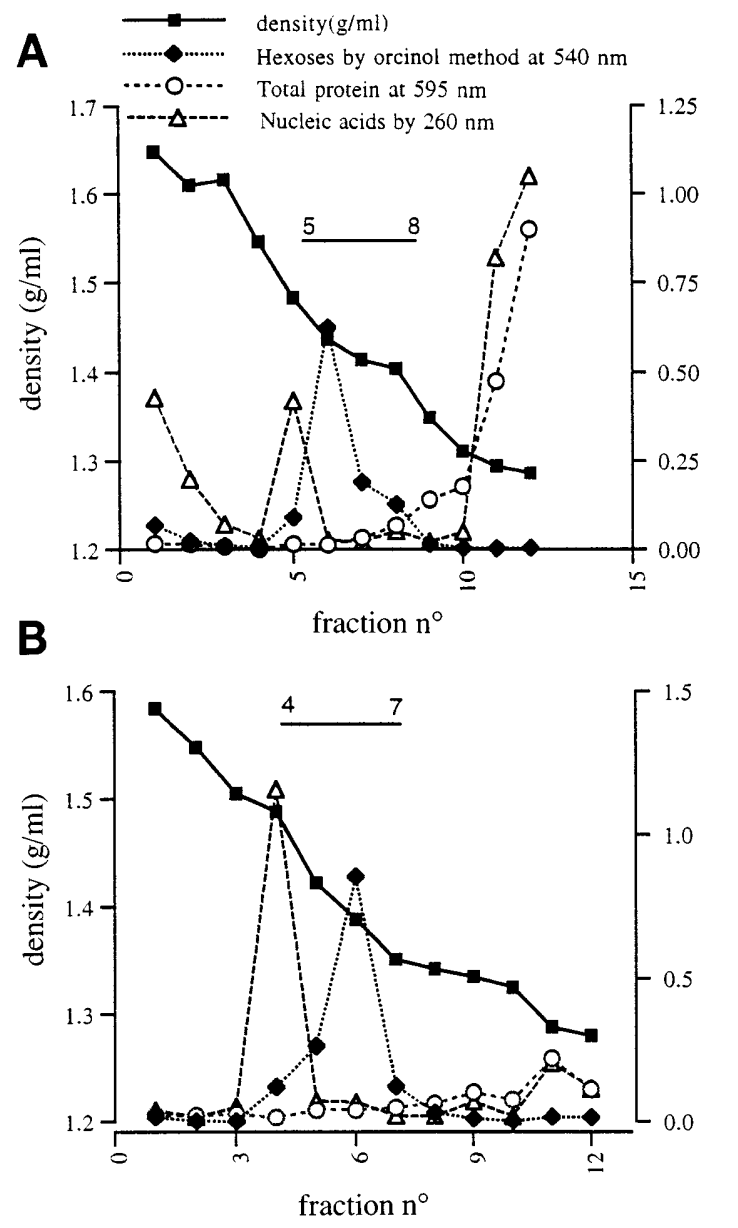

C

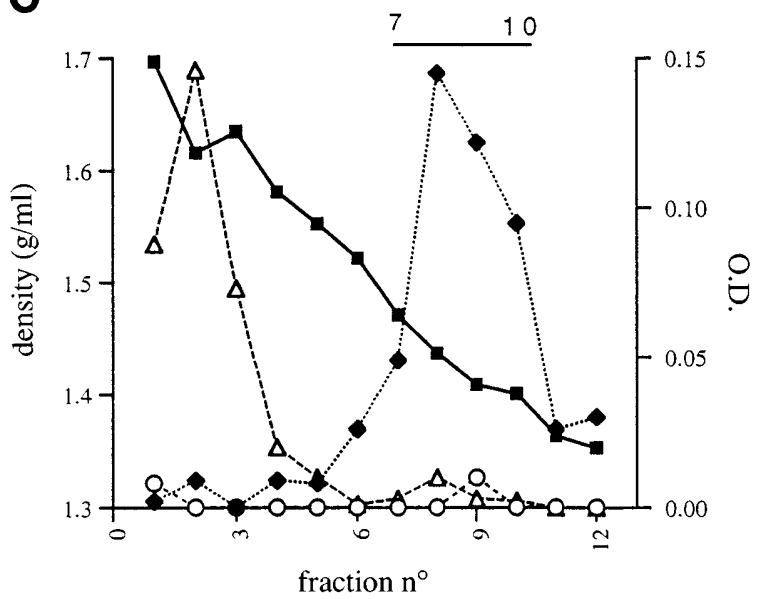

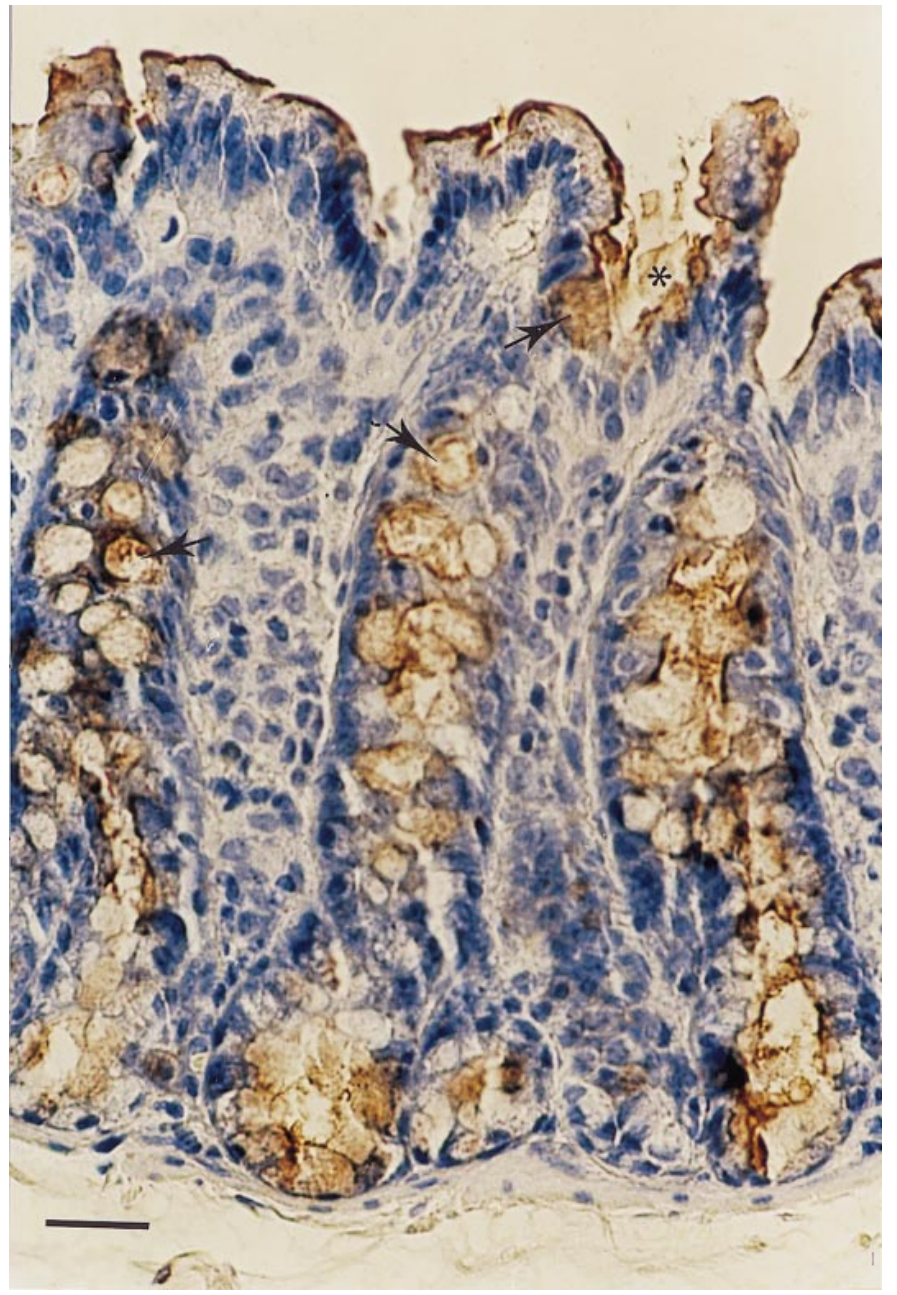

Fig. 2. Immunohistochemistry of paraffin-embedded rat colonic tissue after incubation with 1:1,000 anti-rat colonic mucin antiserum. The section is oriented with intestinal lumen at top. I mmunolabeling is evident as a brown reaction product. Micrograph shows that only goblet cells and mucus blanket are immunoreactive. Arrows and asterisk indicate examples of immunoreactive goblet cells and mucus blanket, respectively. Bar $=10 \mu \mathrm{m}$.

dard curve, producing parallel slopes. This immunoreactive material was distributed on a $\mathrm{CsCl}$ density gradient in a similar way to purified RCM, with a peak at a density of $1.4 \mathrm{~g} / \mathrm{ml}$ (Fig. 3C), which was characteris-

Fig. 1. I solation of mucus glycoproteins from rat colon. Distribution of material after first $\mathrm{CsCl}$ density gradient is shown in A. Gradient had a starting density of $1.40 \mathrm{~g} / \mathrm{ml}$ and contained $4 \mathrm{M}$ guanidinium hydrochloride. After centrifugation, tubes were fractionated, leading to collection of 12 fractions. Distribution of hexoses in first gradient showed peak at density of $1.43 \mathrm{~g} / \mathrm{ml}$ that was characteristic of mucin. Major contaminants in mucin-containing fractions were proteins in top of gradient (fractions 8-12) and nucleic acids in bottom of gradient (fractions 1-6). Mucin-containing fractions indicated by horizontal bar were pooled and loaded on an identical gradient represented in B. Fractions 4-7 of second gradient had a mean density of $1.40 \mathrm{~g} / \mathrm{ml}$, corresponding with a peak in hexoses concentration (B). This gradient induced a complete separation of mucin from proteins but not from nudeic acids. Mucin-containing fractions were then pooled and run on third gradient to separate mucin from nucleic acids (C). This gradient had a starting density of $1.50 \mathrm{~g} / \mathrm{ml}$ and contained $0.2 \mathrm{M}$ guanidinium hydrochloride. In this gradient, DNA was detected in fractions 1-4 whereas hexoses were in fractions 8-10. O.D., optical density. 

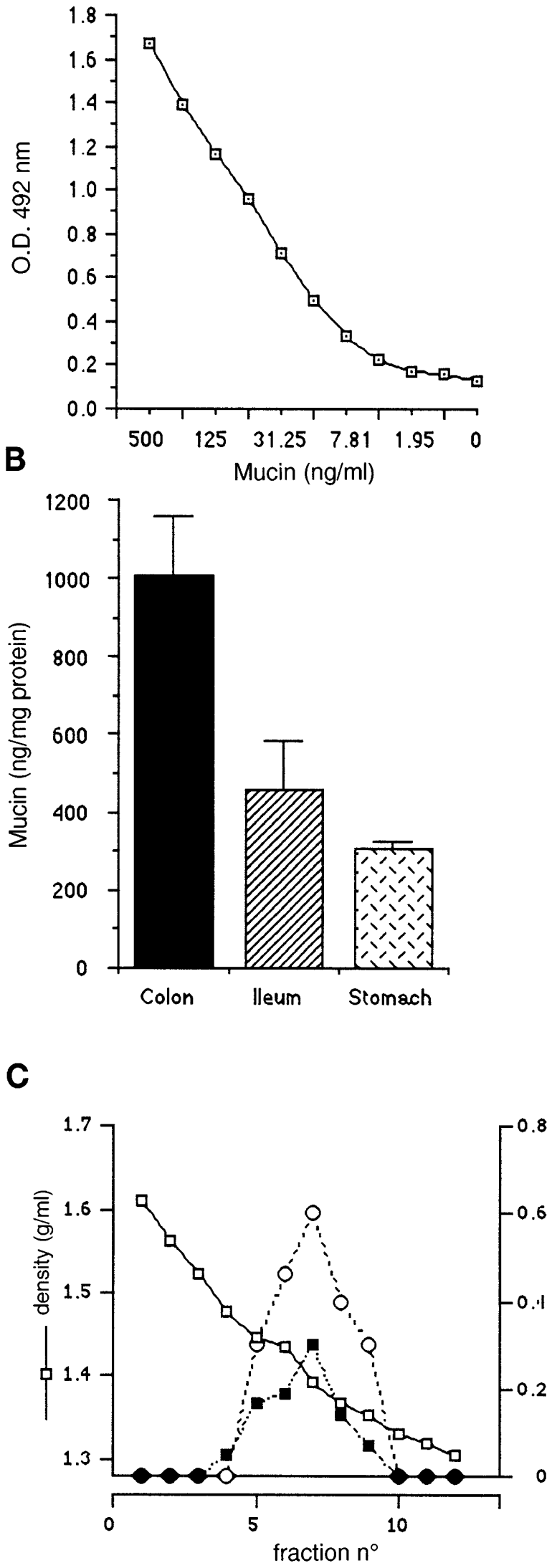

Table 1. Quantitative histology and ELISA assay from isol ated vascularly perfused rat colon after infusion of potential mucus secretagogues

\begin{tabular}{|c|c|c|c|c|c|}
\hline & \multicolumn{3}{|c|}{ Quantitative Histology } & \multirow{2}{*}{\multicolumn{2}{|c|}{ ELISA }} \\
\hline & \multirow{2}{*}{$\begin{array}{l}\text { Percent of } \\
\text { cavitated } \\
\text { mucus cells }\end{array}$} & \multirow{2}{*}{$\begin{array}{l}\text { Number } \\
\text { of mucus } \\
\text { cells/crypt }\end{array}$} & \multirow[b]{2}{*}{$\mathrm{n}$} & & \\
\hline & & & & $\begin{array}{l}\text { Mucin, } \\
\mu \mathrm{g} / \mathrm{mg} \text { DNA }\end{array}$ & $\mathrm{n}$ \\
\hline Cont & $10.8 \pm 3.0$ & $29.8 \pm 1.5$ & 7 & $103 \pm 14$ & 9 \\
\hline Beth & & & & & \\
\hline$\mu \mathrm{M})$ & $10.4 \pm 2.5$ & $16.9 \pm 1.3^{*}$ & 6 & $958 \pm 204^{*}$ & 0 \\
\hline BBS (100 nM) & $8.8 \pm 1.9$ & $19.2 \pm 1.0 *$ & 6 & $897 \pm 140 *$ & 9 \\
\hline VIP $(100 \mathrm{nM})$ & $22.3 \pm 4.0^{*}$ & $25.1 \pm 1.4$ & 4 & $574 \pm 76^{*}$ & 10 \\
\hline I soproterenol (1 & & & & & \\
\hline & $7.2 \pm 1.0$ & $30.7 \pm$ & 4 & $119 \pm 2$ & 5 \\
\hline PYY (10 nM) & $30.2 \pm 2.8^{*}$ & 29. & 5 & $264 \pm 27 *$ & \\
\hline tGLP-1 (10 nM) & $9.1 \pm 1.0$ & $32.4 \pm 1.3$ & 4 & $169 \pm 45$ & 5 \\
\hline Serotonin $(5 \mu \mathrm{M})$ & $32.0 \pm 2.7 *$ & $27.4 \pm 1.3$ & 5 & $451 \pm 51 *$ & 6 \\
\hline $\mathrm{dmPGE}_{2}(2.5 \mu \mathrm{M})$ & $35.7 \pm 4.2 *$ & $21.4 \pm 1.8^{*}$ & 4 & $537 \pm 83 *$ & - \\
\hline SNP (1 mM) & $19.9 \pm 4.5$ & $30.6 \pm 1.4$ & 4 & $269 \pm 25^{*}$ & 6 \\
\hline
\end{tabular}

Values are means $\pm \mathrm{SE} ; \mathrm{n}=$ no. of animals. $* \mathrm{P}<0.05$ compared with control group. Control group underwent a 10-min equilibration period followed by a 30-min period during which Krebs-Henseleit buffer supplemented with 3\% BSA was administered to the vascular inflow. A reduced number of mucus cells indicated a release of mucin from colonic mucosa, and cavitation of mucus cells was the hallmark of accelerated mucus discharge by a process of compound exocytosis. BBS, bombesin; VIP, vasoactive intestinal peptide; $P Y Y$, peptide $Y Y$; tGLP, truncated glucagon-like peptide; dmPGE 2 , dimethyl-PGE ${ }_{2}$; SNP, sodium nitroprusside.

tic of mucins (34). No immunoreactive material was present on the top or on the bottom of the gradient.

\section{Release of Colonic Mucus by Cholinergic and} Adrenergic Agonists

Intra-arterial infusion of $200 \mu \mathrm{M}$ bethanechol in the isolated vascularly perfused rat colon evoked a sharp increase in mucin secretion (Table 1). As shown in Fig. 4 , the effect of bethanechol was concentration-dependent over the range 10-200 $\mu \mathrm{M}$. The first significant response was obtained with $100 \mu \mathrm{M}$ bethanechol. This mucin discharge was associated with a decrease in the number of stained mucus cells per crypt section as compared with the control group (Table 1, Fig. 5). Isoproterenol $(1 \mu \mathrm{M})$ did not induce any significant increase in the release of colonic mucus (119 \pm 24 $\mu \mathrm{g} / \mathrm{mg}$ DNA, $\mathrm{n}=5, \mathrm{P}>0.05)$.

Total luminal contents in response to bethanechol and isoproterenol are shown in Table 2. Bethanechol

Fig. 3. Standard curve, cross-reactivity of prepared mucin antiserum with rat gastrointestinal scrapings, and $\mathrm{CsCl}$ gradient density profile of colonic luminal content. A: calibration curve of ELISA. Mucin was diluted in PBS-Tween-bovine albumin buffer to contain 0-500 ng mucin $/ \mathrm{ml}$. ELISA was performed as described in MATERIALS AND METHODS. Points represent mean of 2 replicate samples for each concentration of purified mucin. B: cross-reactivity of prepared mucin antiserum with rat gastrointestinal scrapings. Scrapings were obtained as described in MATERIALS AND METHODS and analyzed for mucin reactivity. $\mathrm{C}: \mathrm{CsCl}$ gradient density profile of colonic luminal content. Samples were first homogenized in homogenization buffer and alkylated by addition of $0.25 \mathrm{M}$ iodoacetamide. They were then centrifuged at $100,000 \mathrm{~g}$ for $70 \mathrm{~h}$ at $4^{\circ} \mathrm{C}$, separated into fractions, and dialyzed against water before assay. Starting density of $\mathrm{CsCl}$ gradient was $1.40 \mathrm{~g} / \mathrm{ml}$, and gradient contained $4 \mathrm{M}$ guanidinium hydrochloride. 


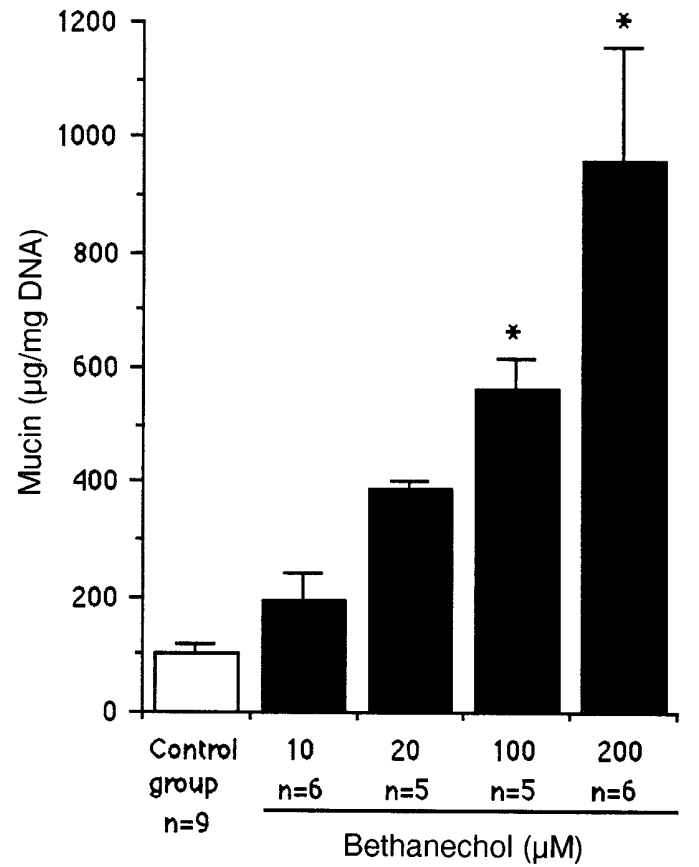

Fig. 4. Effects of increasing doses of bethanechol on mucin secretion in isolated vascularly perfused rat colon. Data are means $\pm \mathrm{SE}$. $* \mathrm{P}<$ 0.05 vs. control group.

$(200 \mu \mathrm{M})$ led to a significant increase in luminal content recovered from the lumen, but luminal DNA content was similar to that observed in the control group (Table $2)$. On the contrary, isoproterenol $(1 \mu \mathrm{M})$ did not modify theluminal content.

\section{Neuropeptides and Mucin Release}

Intra-arterial administration of $100 \mathrm{nM}$ VIP induced colonic mucin discharge (Table 1). On stimulation with $10 \mathrm{nM}$ VIP, the rise in mucin release was less pronounced (Fig. 6A). A greater proportion of cavitated goblet cells was found in loops submitted to intraarterial infusion of VIP as compared with controls (Table 1$)$. The effects of TTX $(1 \mu \mathrm{M})$ and atropine (10 $\mu \mathrm{M}$ ) were tested on intra-arterial infusion of $100 \mathrm{nM}$ VIP. As shown in Fig. 6A, pretreatment with TTX abolished VIP-induced mucin release $(P<0.05$ vs. VIP alone). In contrast, atropine did not inhibit the mucin secretory response. In control experiments (without VIP), TTX $(1 \mu \mathrm{M})$ or atropine $(10 \mu \mathrm{M})$ alone had no effect on mucin secretion (110 $\pm 8 \mu \mathrm{g} / \mathrm{mg} D N A, n=6$, $\mathrm{P}>0.05$, and $97 \pm 12 \mu \mathrm{g} / \mathrm{mg} \mathrm{DNA}, \mathrm{n}=6, \mathrm{P}>0.05$, respectively). As shown in Table 2, VIP (100 nM) induced a small increase in luminal content that was not associated with a significant rise in luminal DNA content.

BBS (100 nM) produced a sharp rise in the discharge of immunoreactive material (Table 1). Thin section of tissue demonstrated that colonic preparations exposed to $100 \mathrm{nM}$ BBS for 30 min exhibited a decrease in the number of stained mucus cells compared with control preparations (Fig. 5, Table 1). In contrast, BBS infusion did not modify the percentage of cavitated mucus cells. As shown in Fig. 6B, mucin secretion induced by BBS was completely abolished by pretreatment with $1 \mu \mathrm{M}$ TTX. Atropine $(10 \mu \mathrm{M})$ decreased BBS-stimulated coIonic mucin secretion by $60 \%$ (Fig. 6B).

CGRP, at final concentrations up to $5 \mathrm{nM}$, did not elicit any release of mucin $(91 \pm 10 \mu \mathrm{g} / \mathrm{mg}$ DNA, $n=6$, $P>0.05)$, whereas a significant increase in total Iuminal content was observed (Table 2).

\section{Release of Col onic Mucin by Hormones} of the Distal Gut

Intra-arterial infusion of PYY (10 nM) in the isolated vascularly perfused rat col on induced release of colonic mucin (Table 1). As shown in Fig. 7A, the responses were related to the concentration of PYY over the range 0.01-10 nM. Numerous goblet cells became deeply cavitated after $30 \mathrm{~min}$ of $10 \mathrm{nM}$ PYY stimulation (Table 1).

In contrast, intra-arterial truncated glucagon-like peptide-1 (10 nM) did not induce a significant increase in mucin release $(169 \pm 45 \mu \mathrm{g} / \mathrm{mg}$ DNA, $n=5, P>0.05$ vs. control group).

The effect of serotonin on mucin secretion is shown in Fig. 7B. The mucinlike immunoreactivity was $451 \pm 51$ $\mu \mathrm{g} / \mathrm{mg}$ DNA, $\mathrm{n}=6, \mathrm{P}<0.05$, and $245 \pm 24 \mu \mathrm{g} / \mathrm{mg}$ DNA, $\mathrm{n}=6, \mathrm{P}<0.05$, after 5 and $1 \mu \mathrm{M}$ serotonin, respectively. Stained mucus cells with apical membrane cavitation were very numerous after administration of $5 \mu \mathrm{M}$ serotonin (Table 1, Fig. 5). The response to $5 \mu \mathrm{M}$ serotonin was unaffected by intra-arterial TTX $(1 \mu \mathrm{M})$ (373 $\pm 32 \mu \mathrm{g} / \mathrm{mg}$ DNA, $\mathrm{n}=6, \mathrm{P}>0.05$ vs. $5 \mu \mathrm{M}$ serotonin al one).

Release of Col onic Mucin by Mediators of theImmuneSystem

Intra-arterial perfusion of bromolasalocid $(20 \mu \mathrm{M})$, a degranulator of connective and mucosal mast cells, produced a modest increase in mucin release: $254 \pm 64$ $\mu \mathrm{g} / \mathrm{mg}$ DNA ( $\mathrm{n}=5, \mathrm{P}<0.05$ vs. control group). In contrast, luminal administration of $20 \mu \mathrm{M}$ bromolasalocid failed to induce significantly mucin discharge: $120 \pm 15 \mu \mathrm{g} / \mathrm{mg}$ DNA ( $n=6, P>0.05$ vs. control group).

Intra-arterial administration of a stable analog of $\mathrm{PGE}_{2}\left(\mathrm{dmPGE}_{2}, 2.5 \mu \mathrm{M}\right)$ in the isolated vascularly perfused rat colon led to a fivefold increase in mucin secretion (Table 1, Fig. 8). By light microscopy, a rise in the percentage of cavitated mucus cells was observed. The number of stained mucus cells per crypt section was al so significantly reduced (Table 1 ).

As can be seen from Fig. 8, I L-1 $\beta(0.25 \mathrm{nM})$ provoked a modest rise in the secretion of mucin. The mucinlike immunoreactivity release was $200 \pm 35 \mu \mathrm{g} / \mathrm{mgDNA}(\mathrm{n}=6$, $\mathrm{P}<0.05$ vs. control group) after administration of IL-1 $\beta$.

SNP (1 mM), an NO generator, increased mucin secretion (Table 1, Fig. 8). By morphological analysis, SNP showed a tendency to increase the percentage of cavitated mucus cells, although this value did not achieve statistical significance (Table 1).

\section{DISCUSSION}

To measure mucus released from isolated vascularly perfused rat preparation, we developed a sandwich 


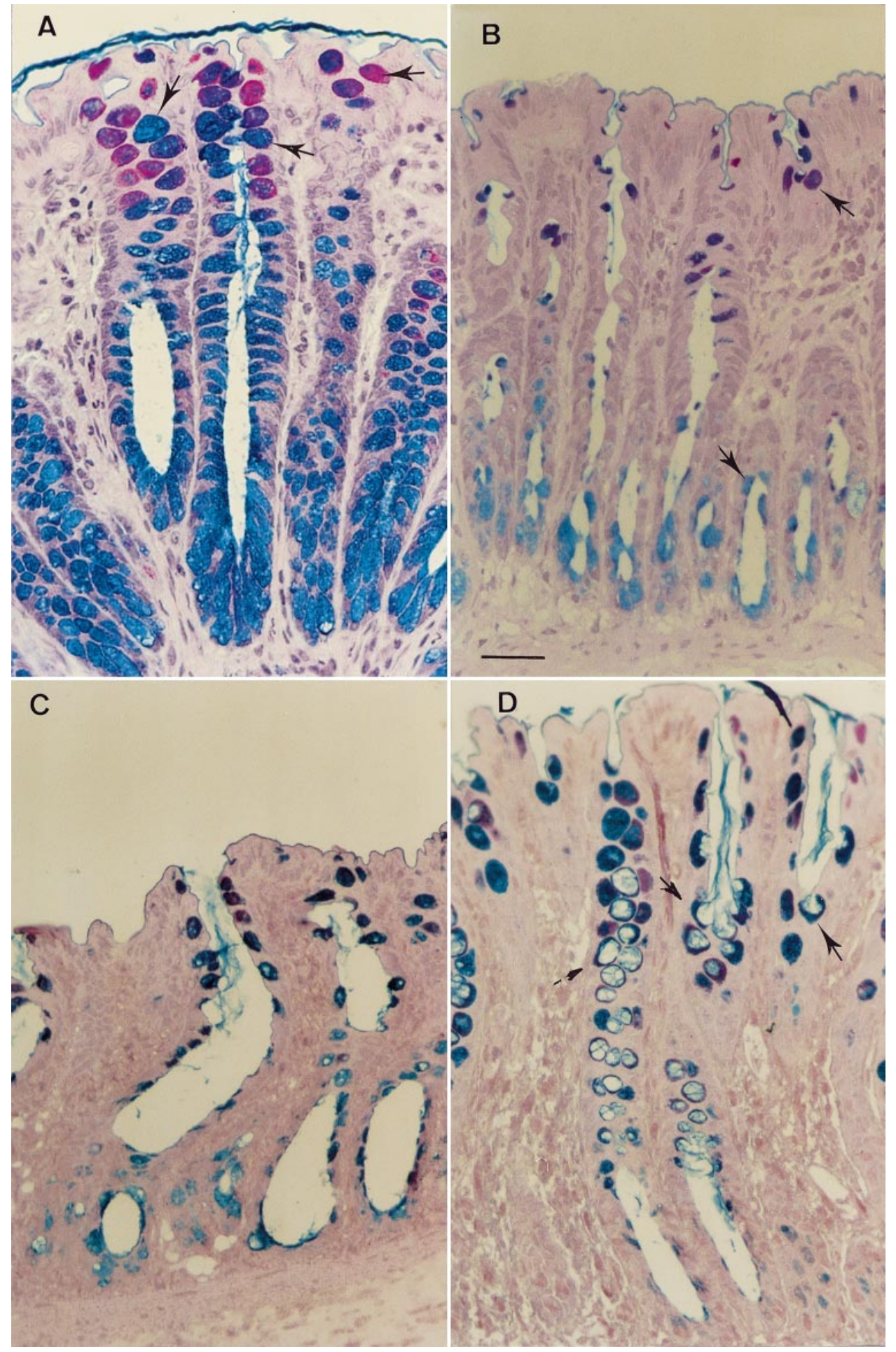

Fig. 5. Thin-section histology of perfused rat colon. Bar $=10 \mu \mathrm{m}$. A: crypt of a control preparation. This colonic loop underwent 10-min equilibration pe riod, followed by 30-min period during which Krebs-Henseleit buffer supplemented with 3\% BSA was administered to the vascular inflow. Goblet cells (alcian blue/periodic acid-Schiff stained) are filled with mucus. Arrows indicate examples of stained mucus cells. B: crypts of perfused rat colon after 30-min perfusion with $200 \mu \mathrm{M}$ bethanechol. Few stained mucus cells (arrows) were observed al ong the length of the crypt. C: colonic mucosa after administration of $100 \mathrm{nM}$ bombesin (BBS) for $30 \mathrm{~min}$. Few stained mucus cells were observed along the length of the crypt. D: colonic crypt after 30-min perfusion with $5 \mu \mathrm{M}$ serotonin. Numerous mucus cells with deep cavitation of apical cell surface were easily observed (arrows).

ELISA for RCMs. For this purpose, RCMs were purified using a validated procedure (33), and these purified glycoproteins were then used to elicit a polyclonal antiserum. Because glycan structures are also present in glycolipids and in other glycoproteins, it was necessary to obtain a polyclonal antiserum that reacts primarily with the protein part of RCM. Our data demonstrated that anti-RCM antiserum no longer recognized RCM after proteinase K digestion, thus indicat- ing that antigenic determinants were localized to a nonglycosylated segment of colonic mucins. In agreement with Satchithanandam et al. (30), our study also showed that the anti-RCM antiserum is highly specific for antigenic determinants found only in scrapings of rat digestive tract. The anti-RCM antiserum detected only mucus blanket and intracellular mucin granules in goblet cells by immunohistochemistry. Furthermore, the immunoreactive material released from isolated 
Table 2. Total luminal content (fluid content + adherent mucus ge) and luminal DNA content after infusion of potential mucus secretagogues in isolated vascularly perfused rat col on

\begin{tabular}{|c|c|c|c|}
\hline & $\begin{array}{l}\text { Luminal } \\
\text { Content, } \\
\mathrm{mg} / \mathrm{cm}\end{array}$ & $\begin{array}{l}\text { Luminal } \\
\text { DNA Content, } \\
\% \text { of total DNA }\end{array}$ & $\mathrm{n}$ \\
\hline Control group & $129 \pm 07$ & $0.65 \pm 0.10$ & 9 \\
\hline Bethanechol $200 \mu \mathrm{M}$ & $176 \pm 16 *$ & $0.44 \pm 0.10$ & 6 \\
\hline Bethanechol $100 \mu \mathrm{M}$ & $154 \pm 04$ & $0.60 \pm 0.10$ & 5 \\
\hline Bethanechol $20 \mu \mathrm{M}$ & $157 \pm 09$ & $0.57 \pm 0.08$ & 5 \\
\hline Bethanechol $10 \mu \mathrm{M}$ & $134 \pm 08$ & $0.40 \pm 0.10$ & 6 \\
\hline I soproterenol $1 \mu \mathrm{M}$ & $117 \pm 23$ & $0.45 \pm 0.08$ & 5 \\
\hline BBS 100 nM & $150 \pm 13$ & $0.80 \pm 0.20$ & 9 \\
\hline BBS $10 \mathrm{nM}$ & $146 \pm 07$ & $0.62 \pm 0.12$ & 5 \\
\hline VIP $100 \mathrm{nM}$ & $167 \pm 11 *$ & $0.68 \pm 0.06$ & 10 \\
\hline VIP $10 \mathrm{nM}$ & $151 \pm 03$ & $0.56 \pm 0.10$ & 6 \\
\hline CGRP 5 nM & $163 \pm 09 *$ & $0.48 \pm 0.07$ & 6 \\
\hline PYY $10 \mathrm{nM}$ & $113 \pm 13$ & $0.70 \pm 0.13$ & 6 \\
\hline PYY $1 \mathrm{nM}$ & $130 \pm 08$ & $0.64 \pm 0.05$ & 6 \\
\hline PYY $0.1 \mathrm{nM}$ & $134 \pm 01$ & $0.76 \pm 0.10$ & 4 \\
\hline tGLP-1 $10 \mathrm{nM}$ & $125 \pm 18$ & $0.50 \pm 0.15$ & 5 \\
\hline Serotonin $5 \mu \mathrm{M}$ & $153 \pm 10$ & $0.43 \pm 0.10$ & 6 \\
\hline Serotonin $1 \mu \mathrm{M}$ & $121 \pm 10$ & $0.41 \pm 0.10$ & 6 \\
\hline $\mathrm{dmPGE}_{2} 2.5 \mu \mathrm{M}$ & $166 \pm 10 *$ & $0.56 \pm 0.14$ & 5 \\
\hline SNP $1 \mathrm{mM}$ & $197 \pm 04 *$ & $0.83 \pm 0.14$ & 6 \\
\hline SNP $0.1 \mathrm{mM}$ & $142 \pm 16$ & $0.55 \pm 0.15$ & 5 \\
\hline 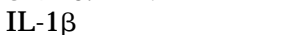 & $151 \pm 08$ & $0.40 \pm 0.07$ & 6 \\
\hline Bromolasalocid $20 \mu \mathrm{M}$ & $164 \pm 11 *$ & $0.45 \pm 0.10$ & 5 \\
\hline
\end{tabular}

Values are means \pm SE. CGRP, calcitonin gene-related peptide; IL, interleukin. $* \mathrm{P}<0.05$ compared with control group.

vascularly perfused rat colon after administration of two well-known mucus secretagogues (bethanechol or $\left.\mathrm{dmPGE}_{2}\right)(20,25)$ had the same affinity with the antiserum as the purified mucin. Overall, these data suggest a selective recognition of epitopes bel onging to the mucus fraction of intestinal contents by the present antiserum. The sandwich ELISA developed in this study is then suitable for specific and quantitative determination of colonic mucin in rats. The major advantages of this sandwich method are that the assays are accurate and are carried out in $5 \mathrm{~h}$ with precoated plates and that samples do not need to be purified before use. Consequently, we used it in studies of mucus secretion to measure mucins in diluted and unpurified samples. The interference of other glycoproteins or proteins is negligible.

Studies providing direct evidence for mucin discharge from the colonic epithelium by neurotransmitters and neuropeptides are scarce. Tumoral mucussecreting cell lines were instead used to answer these questions. In the course of characterizing the effect of endogenous factors on colonic mucin secretion, we found that the $\beta$-adrenergic agonist isoproterenol was not a stimulant of mucin discharge in the isolated vascularly perfused rat colon. Similarly, studies performed in organ culture showed that $\alpha$ - and $\beta$-adrenergic agonists did not result in accelerated secretion of mucin from rabbit colon (24). Taken together, adrenergic transmitters do not appear to be major determinants in the regulation of colonic mucin discharge.

The possibility that gastrointestinal neuropeptides may induce col onic mucin secretion has not been clearly explored previously. The present study demonstrated that VIP caused a sharp release of colonic mucus by compound exocytosis. In contrast, Neutra et al. (24) reported that VIP did not accelerate mucin discharge in rabbit small and large intestine in organ culture. In another study consistent with the former investigation

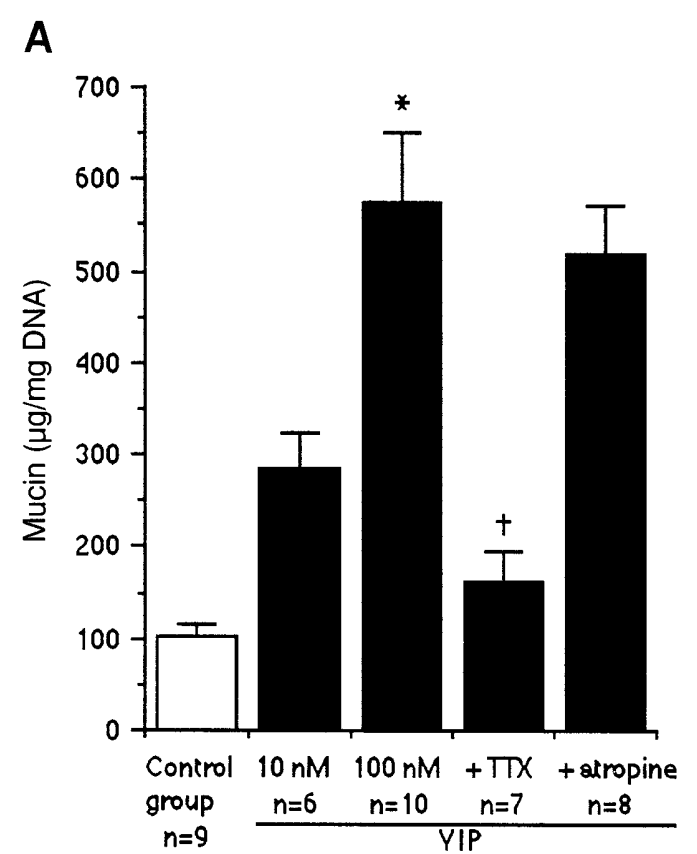

B

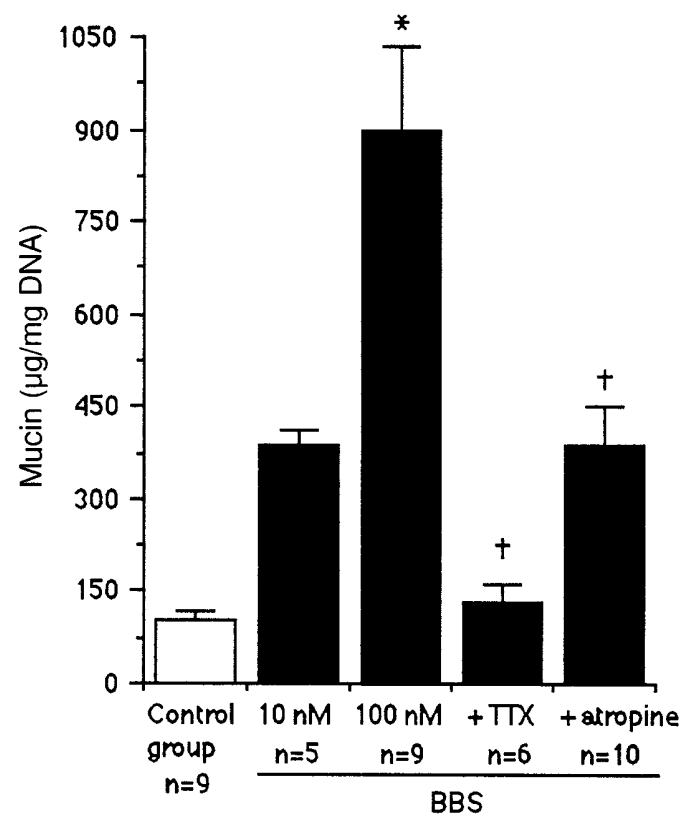

Fig. 6. Effect of 2 neuropeptides [vasoactive intestinal peptide (VIP) and BBS] on mucin secretion in rat colonic preparations. A: dose related effect of VIP on mucin discharge and effect of TTX $(1 \mu \mathrm{M})$ or atropine $(10 \mu \mathrm{M})$ on secretory response induced by $100 \mathrm{nM}$ VIP. Colonic preparations were pretreated for 10 min with TTX or atropine before being challenged for $30 \mathrm{~min}$ with $100 \mathrm{nM}$ VIP. Values are means $\pm S E . * P<0.05$ vs. control group. $\dagger P<0.05$ vs. $100 \mathrm{nM}$ VIP alone. B: doserelated effect of BBS on mucin secretion and effect of TTX or atropine on secretory response induced by $100 \mathrm{nM}$ BBS. Data are means $\pm \mathrm{SE} . * \mathrm{P}<0.05$ vs. control group. $\dagger \mathrm{P}<0.05$ vs. 100 nM BBS alone. 
A

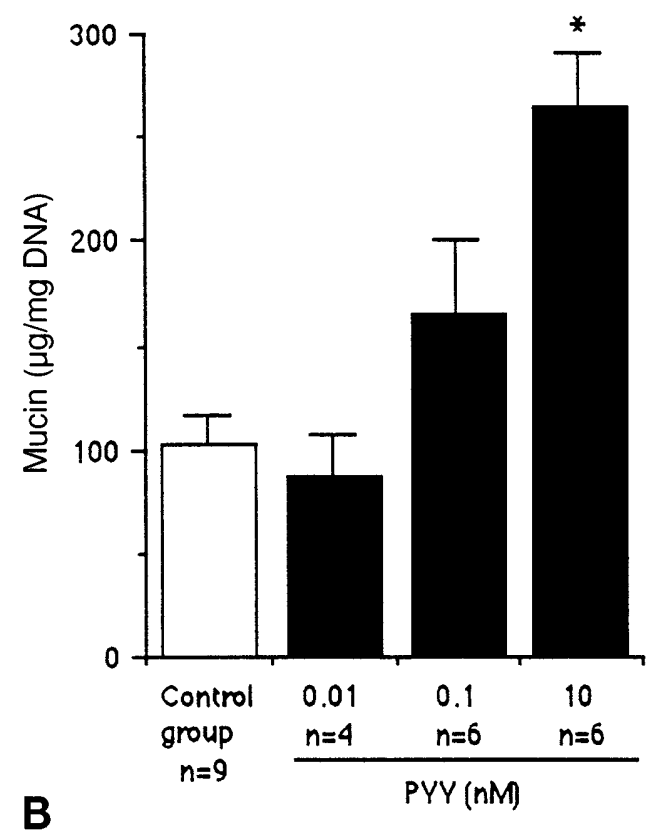

B

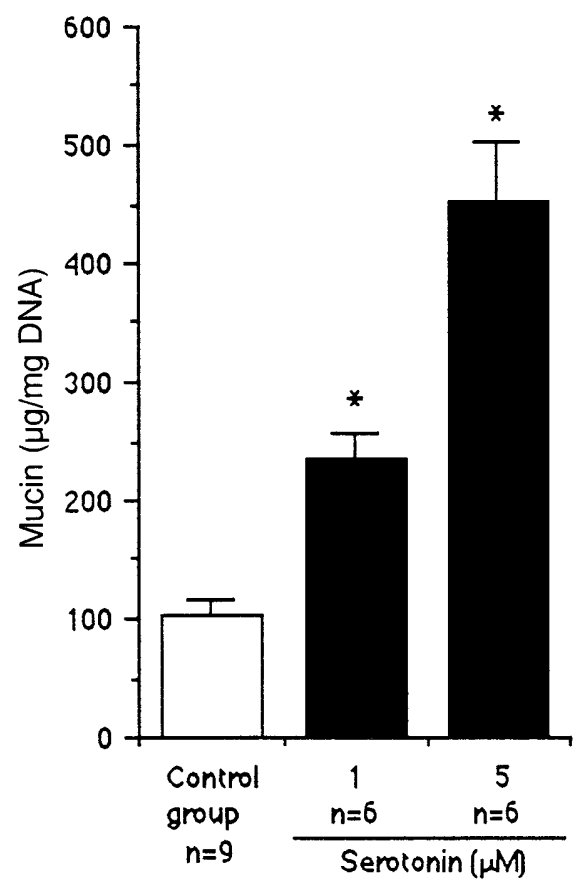

Fig. 7. Effects of peptide $Y Y$ (PYY) and serotonin on mucin release. A: Iuminal mucin secretion in response to PYY. Values are means \pm $\mathrm{SE} . * \mathrm{P}<0.05$ vs. control group. B: luminal mucin secretion in response to serotonin, the major product of the enterochromaffin cells. Values are means $\pm \mathrm{SE} . * \mathrm{P}<0.05$ vs. control group.

(19), VIP $(1 \mu \mathrm{M})$ did not alter basal mucin secretion in theHT-29-CL.16E colonic cell line, despitethe presence of functional VIP-receptors. An attractive hypothesis that could explain the difference between these results is that VIP stimulates mucin release indirectly through the activation of the enteric nervous system, which is left intact in the isolated vascularly perfused rat preparation. This hypothesis is supported by the observation that pretreatment with the neurotoxin TTX completely abolished VIP-evoked mucin secretion from rat colon but had no effect on baseline mucin discharge. This result is in agreement with early observations indicating that enteric nerves may be involved in VIPstimulated intestinal secretion (16). I ndeed, it has been pointed out that the VIP effect on bicarbonate secretion is mediated by the enteric nervous system in rabbit proximal duodenum (16). In our study, the possibility that muscarinic receptors participate in the VIPevoked mucin secretion may be excluded, because

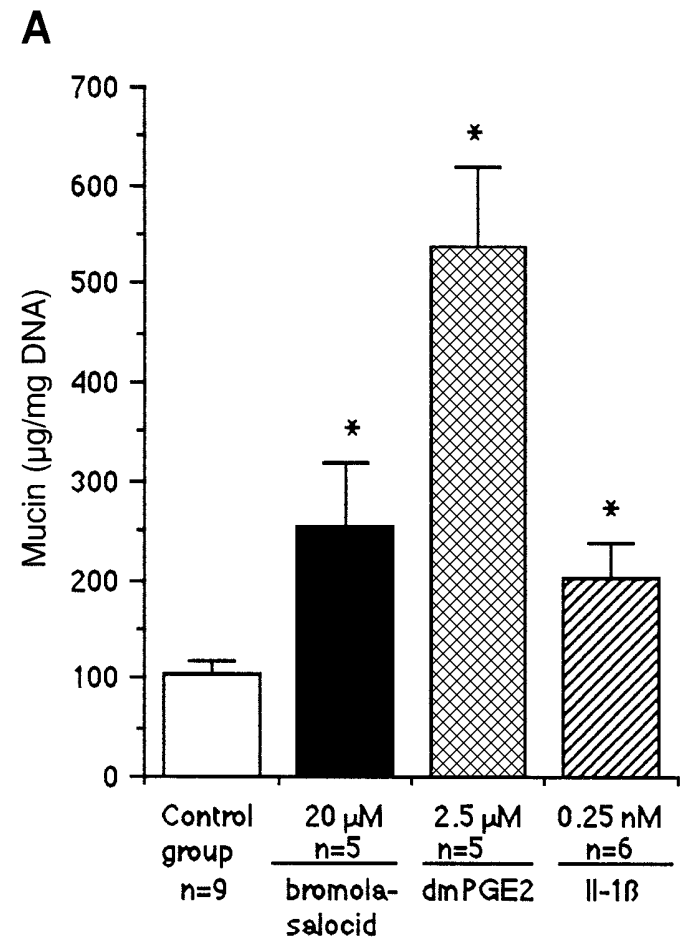

B

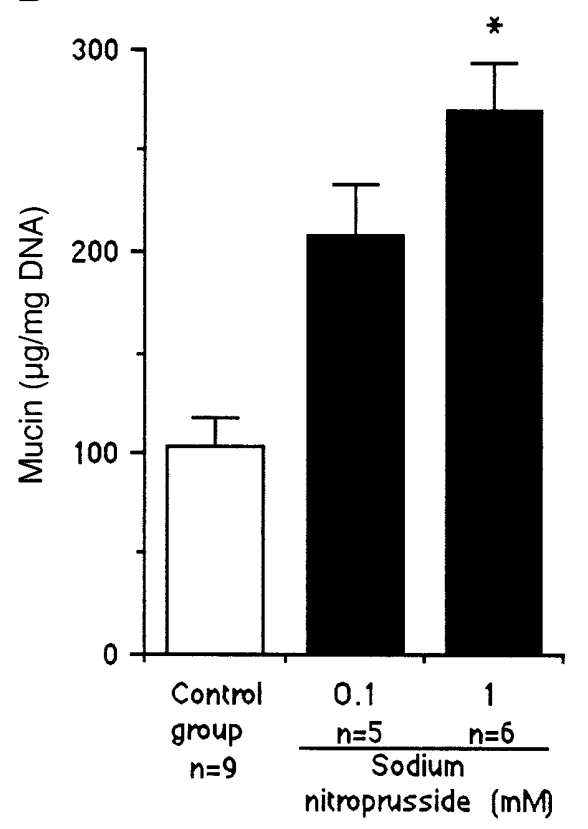

Fig. 8. Effects of bromolasalocid, dimethyl-PGE $2\left(\mathrm{dmPGE}_{2}\right)$, interleukin (IL)-1ß, (A) and sodium nitroprusside (B) on mucin secretion in isolated vascularly perfused rat colon. $* \mathrm{P}<0.05 \mathrm{vs}$. control group. 
atropine did not alter the secretagogue-induced effect on mucin discharge.

The neuropeptide gastrin-releasing peptide (GRP)/ BBS is another neuropeptide found in mammalian gastrointestinal tract. GRP/BBS is thought to stimulate secretion from endocrine cells in the stomach and intestine (7). The present study showed for the first time that BBS markedly increased the discharge of colonic mucin. Similarly, Hootman and De Ondarza (17) were able to show that, in isolated pancreatic duct, BBS stimulated goblet cell degranulation. Together, these results suggest another secretory function for BBS in the digestive tract. Our morphometric analysis additionally indicated that BBS induced mucus secretion by a mechanism that did not result in the cavitation of apical membrane. This histological picture resembles the aspect of colonic crypts after 30-min perfusion with bethanechol. To gain an insight in the mechanism underlying the BBS-evoked mucus secretion in the isolated vascularly perfused rat colon, TTX or atropine was administered intra-arterially before BBS infusion. Mucin secretion elicited by BBS was completely inhibited by TTX. Interestingly, atropine reduced by $\sim 60 \%$ the BBS-induced mucin response, suggesting a partial cholinergic mediation. Together, these data indicate that BBS evokes mucin discharge through the activation of enteric nerves, part of which involves the participation of muscarinic receptors.

CGRP-containing nerves are found in the submucosal layer of the gut wall. The present study showed that CGRP did not induce mucin output from the isolated vascularly perfused rat colon. Another interesting fact is that luminal DNA content was not modified, although CGRP significantly increased fluid accumulation. Overall, it is likely that the moderate colonic fluid distension induced by fluid accumulation in our model was not sufficient by itself to induce mucosal damage and mucin discharge. This hypothesis is strengthened by the observation that the most potent fluid secretagogues administered in this report (bethanechol, VIP, SNP) did not significantly modify luminal DNA content. Furthermore, histological analysis of the stimulated preparations did not reveal any damage of the epithelium, suggesting that mucin secretion obtained after fluid secretagogues was not induced by nonspecific breakdown of the epithelial barrier and mucosal damage. The conclusion to be drawn from these results is that mucin release from our model is the result of a true secretory response induced by secretagogues and was not the consequence of colonic loop distension and pressure necrosis.

Besides a neural mechanism, the secretion of colonic mucin may also implicate hormonal or local paracrine pathways. Supporting this hypothesis, El-Sahli et al. (8) were able to observe that enteroendocrine $L$ cells in human colon emit long cytoplasmic processes to the neighboring goblet cells, suggesting a paracrine action on mucus secretion. This hypothesis was therefore tested in the present study. $L$ cells produce and secrete PYY, a 36-amino-acid polypeptide hormone that has a variety of biological effects on the gastrointestinal tract, including inhibition of gastric and pancreatic secretion and of gastric emptying and intestinal motility (35). The present study showed that intra-arterial infusion of PYY (10 nM) produced a threefold increase in mucin release. This result is in agreement with our previous finding that PYY (10 nM) induced cavitation of the apical granule mass of goblet cells in the isolated vascularly perfused rat col on (28). In the present study, intra-arterial infusion of PYY mimicking a physiological concentration of the circulating peptide $(0.1 \mathrm{nM})(1$, 2) induced a modest rise in mucin secretion, thus excluding a major hormonal action of this peptide. However, the possibility that PYY exerted a local paracrine action on mucin release cannot be ruled out. Consequently, it is conceivable that PYY, released by intraluminal stimuli, could act locally on mucus cells to protect the col onic mucosa.

The other prominent enteroendocrine cell in the colon is the enterochromaffin cell, which synthesizes the biogenic amine serotonin. Serotonin stimulated mucin secretion from the dog gastric antrum (22). Moore et al. (23) have al so demonstrated that serotonin ( 3 and $5 \mu \mathrm{M}$ ) induces the rel ease of mucin in an isolated loop of rat small intestine. Used at the same concentrations, serotonin also induced a clear rise in colonic mucin secretion in our model. The present study also showed for the first time that this mucus discharge was mediated by compound exocytosis. In contrast, serotonin was without effect on mucin release in rabbit small and large intestine in organ culture (24). It is likely that these discrepancies are related to the different models used.

The accelerated discharge of mucus may also involve resident immune cells of the normal colon, which consist of lymphocytes, macrophages, and mast cells. Several studies performed with isolated gastric mucous cells and the human goblet cell line HT-29-CL.16E showed that mucin was released by several mediators secreted by immune cells $(3,4,18)$. Similarly, the present study demonstrates that several immunoregulatory mediators induce a rise in mucus discharge from col onic goblet cells in rats. Two different populations of mast cells have been identified in the col on: connective tissue mast cells and mucosa mast cells that are found in large number. The present study demonstrated that the degranulator compound bromolasalocid, which acts on both types of mast cells (9), induced a small increase in mucin secretion. Furthermore, luminal administration of bromolasalocid did not induce mucin discharge, thus suggesting that this drug did not directly degranulate goblet cells.

NO is a mediator released by mast cells, but also by macrophages, neutrophils, and enteric nerves. With a model of isolated rat gastric mucous cells, Brown et al. (4) showed that NO donors induced mucin secretion. Subsequently, a specific effect of NO donors to stimulate mucus secretion was described in the goblet cell line HT-29-CL.16E (3). Similarly, the present study demonstrated that NO liberated from SNP caused a concentration-dependent increase in colonic mucin release. Taken together, these results suggest that NO 
may be implicated in the control of gastrointestinal mucin release.

The immunoregulatory cytokine IL-1 is more specifically secreted by macrophages (6). IL-1 has been demonstrated to induce a rise in the release of mucin in explant culture of mouse duodenum (5) and in the goblet cell line HT-29-CL.16E (18). Our observation that IL and SNP elicited an increase in mucin release into the colonic lumen must be tempered because the magnitude of the response was relatively low. It represented at most a doubling of basal secretion calculated from data obtained in a different animal group. Because baseline responses may vary among animal groups, the significance of the results is questionable when rather weak stimulants are tested.

In conclusion, we have provided evidence that the sandwich ELISA is useful to measure accurately mucin secretion in the isolated vascularly perfused rat colon. This approach already led to the demonstration that colonic mucin secretion may be induced by several factors, such as a classical neurotransmitter, two gut neuropeptides, an hormonal peptide of the distal gut, a biogenic amine, and several mediators of the immune system. Additionally, the morphological method enabled us to show that accelerated secretion of mucus is accomplished by two different mechanisms according to the nature of secretagogues. Several factors, including VIP, PYY, and serotonin, induced a phenomenon of compound exocytosis, resulting in deep cavitation of apical membrane surface. On the contrary, bethanechol and BBS provoked mucus secretion by another process, presumably by accel erating single-granule exocytosis.

The kind advice of Dr. C. Vincent is gratefully acknowledged. The authors also thank G. Burlet and A. Desvignes for skillful technical assistance.

Address for reprint requests: P. Plaisancié, Institut National de la Santé et de la Recherche Médicale U-45, Pavillon Hbis, Hôpital Ed. Herriot, 69347 Lyon Cedex 03, France.

Received 3 December 1997; accepted in final form 10 J uly 1998.

\section{REFERENCES}

1. Adrian, T. E., A. J . Bacarese-Hamilton, H. A. Smith, P. Chohan, K. J . Manolas, and S. R. Bloom. Distribution and postprandial release of porcine peptide YY. J . Endocrinol. 113: 11-14, 1987.

2. Bilchik, A. J ., O. J . Hines, T. E. Adrian, D. W. McFadden, J . J . Berger, M. J . Zinner, and S. W. Asley. Peptide YY is a physiological regulator of water and electrolyte absorption in the canine small bowel in vivo. Gastroenterology 105: 1441-1448, 1993.

3. Branka, J . E., G. Vallette, A. J arry, and C. L. Laboisse. Stimulation of mucin exocytosis from human epithelial cells by nitric oxide: evidence for a cGMP-dependent and cGMPindependent pathway. Biochem. J . 323: 521-524, 1997.

4. Brown, J . F., A. C. Keates, P.J . Hanson, and B.J . R. Whittle. Nitric oxide generators and CGMP stimulate mucus secretion by rat gastric mucosal cells. Am. J . Physiol. 265 (Gastrointest. Liver Physiol. 28): G418-G422, 1993.

5. Cohan, V. L., A. L. Scott, C. A. Dinarello, and R. A. Prendergast. I nterleukin-1 is a mucus secretagogue. Cell. I mmunol. 136: 425-434, 1991.

6. Dinarello, C. A. Interleukin-1 and interleukin-1 antogonism. Blood 77: 1627-1652, 1991.
7. Dockray, G. J . Physiology of enteric neuropeptides. In: Physiology of the Gastrointestinal Tract (3rd ed.), edited by L. R. J ohnson. New York: Raven, 1994, p. 169-209.

8. EI-Sahli, M., L. Grimelius, E. Wilander, B. Ryberg, L. Terenius, J . M. Lundberg, and K. Tatemoto. I mmunocytochemical identification of polypeptide YY (PYY) cells in the human gastrointestinal tract. Histochemistry 77: 15-23, 1983.

9. Fargeas, M. J., V. Theodourou, J. Fioramonti, and L. Bueno. Relationship between mast cell degranulation and jejunal myoelectric alterations in intestinal anaphylaxis in rats. Gastroenterol ogy 102: 157- 162, 1992.

10. F orstner, G. G. Signal transduction, packaging and secretion of mucins. Annu. Rev. Physiol. 57: 585- 605, 1995.

11. Forstner, J . F., and G. G. Forstner. Gastrointestinal mucus. In: Physiology of the Gastrointestinal Tract (3rd ed.), edited by L. R. J ohnson. New York: Raven, 1994, p. 1255- 1283.

12. François, C., R. D. Marshall, and A. Neuberger. Carbohydrates in protein. The determination of mannose in hen's egg albumin by radioisotope dilution. Biochem. J . 83: 335-341, 1962

13. Guesdon, J . L., T. Ternynck, and S. Avrameas. The use of avidin-biotin interaction in immunoenzymatic techniques. J. Histochem. Cytochem. 27: 1131-1139, 1979.

14. Hasel beck, A., and W. Hösel. Description and application of an immunological detection system for analyzing glycoproteins on blots. Glycoconj. J . 7: 63- 74, 1990.

15. Hinegardner, T. T. An improved fluorimetric assay for DNA. Anal. Biochem. 39: 197-201, 1971.

16. Hogan, D. L., B. Yao, J . H. Steinbach, and J . I . I senberg. The enteric nervous system modulates mammalian duodenal mucosal bicarbonate secretion. Gastroenterology 105: 410-417, 1993

17. Hootman, S. R., and J . De Ondarza. Regulation of goblet cell degranulation in isolated pancreatic ducts. Am. J . Physiol. 268 (Gastrointest. Liver Physiol. 31): G24-G32, 1995.

18. J arry, A., G. Vallette, J . E. Branka, and C. Laboisse. Direct secretory effect of interleukin-1 via type I receptors in human colonic mucous epithelial cells (HT29-CL.16E). Gut 38: 240-242, 1996.

19. Laburthe, M., C. Augeron, C. Rouyer-Fessard, I. Roumagnac, J . J . Maoret, E. Grasset, and C. Laboisse. Functional VIP receptors in the human mucus-secreting colonic epithelial cell line CL.16E. Am. J . Physiol. 256 (Gastrointest. Liver Physiol 19): G443-G450, 1989.

20. Loeschke, K., T. Schmid, and U. M. Farack. Inhibition by loperamide of mucus secretion in the rat colon in vivo. Eur. J. Pharmacol. 170: 41-46, 1989.

21. McCool, D. J ., M. A. Marcon, J . F. Forstner, and G. G. Forstner. The T84 human colonic adenocarcinoma cell line produces mucin in culture and releases it in response to various secretagogues. Biochem. J . 267: 491-500, 1990.

22. Menguy, R. Regulation of secretion of mucus from the gastric antrum. Ann. NY Acad. Sci. 140: 797-803, 1967.

23. Moore, B. A., K. A. Sharkey, and M. Mantle. Role of 5-HT in cholera toxin-induced mucin secretion in the rat small intestine. Am. J. Physiol. 270 (Gastrointest. Liver Physiol. 33): G1001G1009, 1996

24. Neutra, M. R., L. J . O'Malley, and R. D. Specian. Regulation of intestinal goblet cell secretion. II. A survey of potential secretagogues. Am. J . Physiol. 242 (Gastrointest. Liver Physiol. 5): G380-G387, 1982.

25. Phillips, T. E. Both crypt and villus intestinal goblet cells secrete mucin in response to cholinergic stimulation. Am. J. Physiol. 262 (Gastrointest. Liver Physiol. 25): G327-G331, 1992.

26. Phillips, T. E., C. M. Stanley, and J . Wilson. The effect of 16,16-dimethylprostaglandin $E_{2}$ on proliferation of an intestinal goblet cell line and its synthesis and secretion of mucin glycoproteins. Prostaglandins Leukot. Essent. Fatty Acids 48: 423-428, 1993.

27. Plaisancié, P., C. Bernard, J . A. Chayvialle, and J . C. Cuber. Regulation of glucagon-like peptide-1-(7-36) amide secretion by intestinal neurotransmitters and hormones in the isolated vascularly perfused rat colon. Endocrinology 135: 23982403, 1994.

28. Plaisancié, P., A. Bosshard, J . C. Meslin, and J . C. Cuber. Colonic mucin discharge by a cholinergic agonist, prostaglandins 
and peptide $Y Y$ in the isolated vascularly perfused rat colon. Digestion 58: 168-175, 1997.

29. Sakata, T., and W. V. E ngelhardt. I nfluence of short chain fatty acids and osmolality on mucus release in rat colon. Cell Tissue Res. 219: 371-377, 1981.

30. Satchithanandam, S., M. M. Cassidy, A. T. Kharroubi, R. J . Calvert, A. R. Leeds, and G. V. Vahouny. Alterations in rat intestinal mucin patterns following luminal infusion of acetylsalicylic acid and prostaglandins derivatives. Dig. Dis. Sci. 35: 1518-1527, 1990.

31. Specian, R. D., and M. R. Neutra. Regulation of intestinal goblet cell secretion. I. Role of parasympathetic stimulation. Am. J . Physiol. 242 (Gastrointest. Liver Physiol . 5): G370-G379, 1982
32. Specian, R. D., and M. G. Oliver. Functional biology of intestinal goblet cells. Am. J . Physiol. 260 (Cell Physiol. 29): C183-C193, 1991.

33. Tytgat, K. M. A.J ., F. J . Bovelander, F. J . M. Opdam, A. W. C. Einerhand, H. A. Büller, and J . Dekker. Biosynthesis of rat MUC2 in colon and its analogy with human MUC2. Biochem. J . 309: 221-229, 1995.

34. Tytgat, K. M. A. J ., H. A. Büller, F. J . M. Opdam, Y. C. Kim, A. W. C. Einerhand, and J. Dekker. Biosynthesis of human colonic mucin: MUC2 is the prominent secretory mucin. Gastroenterology 107: 1352-1363, 1994.

35. Walsh, J . H. Gastrointestinal hormones. In: Physiology of the Gastrointestinal Tract (3rd ed.), edited by L. R. J ohnson. New York: Raven, 1994, p. 2- 128.

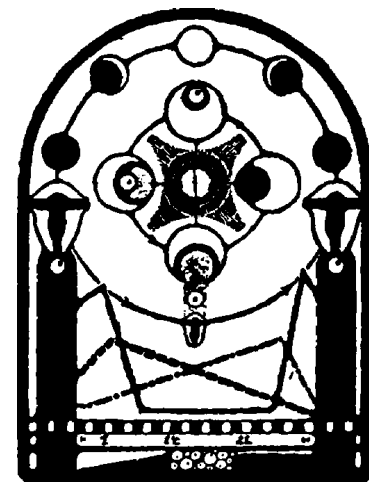

